\title{
Fighting "Change" in Congressional Campaigns
}

\author{
Randall E. Adkins and David A. Dulio
}

The results of the 2008 election cycle were historic. After all of the votes were tallied, Senator Barack Obama garnered more votes than his principal opponent, Senator John McCain. Although the election brought the first African-American president to Washington, there is a lot more to the story. Congressional campaigns are often overshadowed by the presidential campaign and thereby left out of the post-election discussion. This is a mistake. Campaigns for House and Senate seats are just as important to how the nation will move ahead on serious issues in the coming years. Congress, after all, is responsible for delivering to President Obama the legislation that makes up his agenda. In 2008 congressional Democrats increased their margins in both the House and the Senate and returned the Democratic Party to unified control of government. The articles in this special issue of the American Review of Politics examine six important congressional campaigns and help tell the story of the 2008 election, beyond Barack Obama's historic victory.

\section{The National Political Setting}

Primary among the factors that made up the political landscape in 2008 was President George W. Bush. Indeed, his public approval rating of 25 percent in October of 2008 was near historic lows. ${ }^{1}$ In fact, President Nixon's approval ratings were at 24 percent at the time he resigned from office due to the Watergate scandal. ${ }^{2}$ The public's perception of President Bush created a highly advantageous context for most Democrats running for office and Republicans were effectively "on their heels" throughout the election cycle battling their challengers as best they could by dismissing President Bush and his unpopular policy choices. In fact, President Bush played a key role in many of the races tracked by the articles that follow; he was a common target of Democratic candidates, party committees, and outside groups trying to move voters to their side.

RANDALL E. ADKINS is an associate professor and Chair of the Graduate Program in the Department of Political Science at the University of Nebraska at Omaha. DAVID A. DULIO is an associate professor of political science at Oakland University in Rochester, MI.

The American Review of Politics, Vol. 30, Summer, 2009: 107-113

(C)2009 The American Review of Politics 
The political landscape was also full of difficult issues including an unpopular war, a declining economy, growing budget deficits, and others. These were serious problems and understandably the public was in the mood for a change. Pollsters often ask the public in opinion surveys, "Do you feel things in this country are generally going in the right direction or do you feel things have pretty seriously gotten off on the wrong track?" Clearly, this question taps into how respondents view the economic and political climate. In 2008, the public mood was bad. An unbelievable 89 percent of the public said the country was off on the wrong track in late October, with fewer than one-in-ten agreeing that the U.S. was headed in the right direction.

While George W. Bush had low approval numbers, those of Congress, which was controlled by the Democrats, were even worse. It seemed, however, as if Republican incumbents were faring worse than their Democratic counterparts for two reasons. First, while each incumbent was certainly partially responsible for those low ratings, congressional approval ratings appear to be tied to the performance of the leadership in the House and Senate. In other words, while the public may not approve of the Congress as a whole, they tend to like their own member of Congress (see Fenno 1978). Second, empirical evidence also suggests that when poor public approval ratings of a sitting president are coupled with a poor economy, incumbents of the president's party are more likely to face higher quality challengers who are well funded (see Jacobson and Kernell 1983). This is exactly the scenario Republicans were up against in 2008 - high quality and well funded Democratic challengers.

Combined, these factors gave Democrats an initial advantage and created a context in which it would be very difficult for Republicans to be successful. Led by Barack Obama, the Democrats took advantage of a builtin theme-change. The Obama campaign did an absolutely masterful job of utilizing the theme of change to connect with voters. Thus, the 2008 presidential election in many ways was less about John McCain and more about George W. Bush and his policies. Democratic congressional candidates did this as well, linking incumbent Republicans to President Bush in stump speeches and campaign advertisements.

\section{Election Aftermath}

Pundits have described the 2008 election results as a "realignment," a "tectonic shift," and a "revolution." However, in spite of the great strength at the top of the Democratic ticket, the Democratic congressional majorities were really no larger than they were in other election cycles where the presidency changed hands from a Republican to a Democrat. Many analysts 
predicted even larger majorities in both chambers than the election results produced, but congressional Democrats fell short of their goals.

Barack Obama defeated John McCain in the popular vote 53 percent to 46 percent, or just over 9.7 million votes. Of presidents selected in election years since 1932 where the party in leadership changed hands, only Franklin Roosevelt and Dwight Eisenhower were elected by larger popular vote margins (to be fair, in 1992 Bill Clinton won $53.0 \%$ of the two-party vote, but only $43 \%$ of the three-party vote).

In the Electoral College vote Obama defeated McCain 365-173. Of presidents selected in election years where the party in leadership changed hands, only Franklin Roosevelt, Dwight Eisenhower, and Ronald Reagan won by larger Electoral College vote margins (to be fair in 1992 Bill Clinton won 370-168). In fact, they won rather handily with 472, 442, and 489 Electoral College votes, respectively.

If only John McCain could have carried the states that George W. Bush carried in 2004, he would have won the presidency. Of the 286 electoral votes that Bush won in 2004, McCain only carried 173 and Barack Obama won the others, in addition to all of the states carried by John Kerry in 2004 (representing 252 electoral votes). From the Republicans Barack Obama stole 113 electoral votes, which were not concentrated in any one region of the country. First, Obama won the state of Iowa, where he also campaigned heavily in 2007 in order to win the Democratic caucuses. Second, he secured the "swing" states of Florida and Ohio. Third, Obama won three western states with growing numbers of Latino voters, including Colorado, Nevada, and New Mexico. Further, he won two traditionally Republican states that have growing urban centers, North Carolina and Virginia. Fifth, he picked off Indiana, which neighbors his home state of Illinois. Finally, Barack Obama even won one Electoral College vote in Nebraska, which allocates its electors using the "district" plan rather than the "unit" rule.

Since 1932, the voters have given the Democrats control over Congress far more often than the Republicans. The Democrats controlled both chambers of Congress from 1933 to 1981 except for the 80th and 83rd Congresses. The Republicans won the Senate in the 97th to 99th Congresses and won control of both chambers starting with the 104th Congress. The Democrats were able to win control of the Senate back in the 107th Congress, but lost it the following election year in 2002. The Democrats wrestled control of both chambers of Congress away from the Republicans in 2006 and were hoping to expand their majorities from the 110th Congress in 2008.

In the Senate the goal of the Democrats was to reach the magic "filibuster-proof" number of 60 , whereby the Republicans would no longer be able to debate a bill indefinitely. Since 1932, the magic number has changed twice. First, the inclusion of the states of Alaska and Hawaii increased the 
number needed to reach cloture. Second, in 1975 the number, originally set at two-thirds of senators present and voting, was reduced to three-fifths. Since 1932, the Democrats achieved the magic number in the 74th to 77 th Congresses, the 88th and 89th Congresses, and the 94th and 95th Congresses. During times when the Republicans held the Senate they never reached the magic number.

In 2008, the Democrats picked off seats held by Republicans in Alaska, Colorado, New Hampshire, New Mexico, North Carolina, Oregon, and Virginia. The Republicans won no seats that were previously held by Democrats. This gave the Democrats a total of 58 seats, two short of their goal. Then, on April 28, 2009, Pennsylvania Senator Arlen Specter switched parties putting the Democrats just one short of the magic number of 60. Further, at the time of this writing it appears as if Democrat Al Franken is going win the court challenge and pick up the Minnesota seat previously held by Republican Norm Coleman. If Franken wins this challenge, the Democrats will have met their goal, but just barely. If Coleman wins this challenge, the Republicans will continue to be in the minority, but the filibuster will still be available to them as a bargaining chip.

In the House the goal of the Democratic leadership was to simply expand the majority. Many analysts thought they would pick up as many as 35 additional seats. ${ }^{7}$ Prior to the election the Democrats controlled 236 seats and the Republicans 199. The Democrats held onto 231 of those seats and picked up 26. Of the seats picked up by the Democrats, all but three were in states won by Barack Obama (Alabama, Arizona, and Idaho). Meanwhile, the Republicans held onto 173 of their seats and picked up only five.

\section{Rationale for the Special Issue}

Congressional Democrats did not meet the goals set for them before Election Day when many analysts predicted that they would add more than 35 seats in the House and attain 60 votes in the Senate. In fact, many political analysts were underwhelmed by what the Democrats accomplished. A report in The Hill, a Capitol Hill newspaper, described the gain in the House as a "blip on the screen instead of a big splash."" Political analyst Charlie Cook reported in the Cook Political Report, “... given the strength of the top of the ticket nationally, one might have thought that the victory would have been more vertically integrated." Clearly, Democrats hoped to ride the "coattails" of an Obama victory and increase their margins in the House and Senate. While Democrats in the Senate may end up with a filibuster-proof majority, it will only come because of Arlen Specter's party switch.

While the Democrats grew their majorities in both houses of Congress, many endangered incumbent Republicans managed to get reelected in an 
election cycle where the dynamics clearly worked against them. In fact, given how strongly the political landscape favored the Democrats and how poorly the Republican brand was perceived, it is surprising that the Democratic congressional victories in 2008 were not of a greater magnitude.

The following articles investigate the 2008 congressional elections from a unique perspective: each examines a congressional seat that was held by one of the most vulnerable Republicans. The collective goal of these articles is to ascertain how these incumbents defended their turf in a year when the political tide is blowing against them.

These cases represent a diverse group. They include both House and Senate campaigns from across the country, along with instances where the incumbent won and successfully defended his or her turf as well as occasions when the seat changed hands. More importantly, all of the races selected were among the most competitive and most expensive of the year. In order to better compare the campaigns, however, the sample does not vary in terms of which party the incumbent represents. In each case a Democratic challenger was running against a G.O.P. incumbent. The races this issue examines are:

- The Kentucky Senate race where incumbent Republican (and Senate Majority Leader) Mitch McConnell defeated Democratic challenger Bruce Lunsford. In this race, McConnell relied on a tried and true defensive campaign strategy for congressional incumbents focusing on what he has done for his home state in terms of influence and benefits.

- The North Carolina Senate race where Democratic challenger Kay Hagan defeated incumbent Republican Elizabeth Dole. Here, a myriad of factors - from the national-level to the changes in the make-up of the electorate - made it very difficult for Dole to defend her seat.

- The Illinois 10th congressional district race where incumbent Republican Mark Kirk defeated Democratic challenger Dan Seals. In this race, a Republican incumbent actually performed better than he did two years prior; it is the classic example of a campaign where the incumbent was "running scared."

- The Michigan 7th congressional district race where Democratic challenger Mark Schauer defeated incumbent Republican Tim Wahlberg. Here, the importance of an incumbent's "fit" with the district he represented was key to his defeat.

- The Ohio 1st congressional district race where Democratic challenger Steve Driehaus defeated incumbent Republican Steve Chabot. In this race, the Democrat ran a strong campaign and knocked off a long-time incumbent with the help of outside groups and the candidacy of Barack Obama. 


\section{2 | Randall E. Adkins and David A. Dulio}

- The Pennsylvania 3rd congressional district race where Democratic challenger Kathy Dahlkemper defeated incumbent Republican Phil English. In this contest, a political neophyte who ran a strong campaign knocked off another long-time incumbent; the story of this challenger is uncommon in congressional campaigns today.

Each article examines the important national- and district-level factors at work in the campaign. There are several district-level elements that are common in each article; these include: a description of the district or state and the electoral and political context of the campaign; the candidates; the strategies and tactics waged by the campaign and outside groups; and an analysis of the factors that helped determine why the winner came out on top.

It is our hope that these articles will help scholars better understand the dynamics of the 2008 congressional races. We believe these case studies convey valuable lessons about how local issues and trends, as well as national forces, impacted each contest. These are important lessons for understanding 2008 beyond the historic presidential election results, but also in looking forward to 2010 and what those elections may bring.

\section{NOTES}

${ }^{1}$ http://www.gallup.com/poll/1723/Presidential-Job-Approval-Depth.aspx [accessed February 24, 2009].

${ }^{2}$ http://www.gallup.com/poll/113770/Bush-Presidency-Closes-34-Approval-61Disapproval.aspx [accessed February 24, 2009].

${ }^{3}$ John B. Judis, "America the Liberal," The New Republic, November 5, 2008, http://www.tnr.com/politics/story.html?id=c261828d-7387-4af8-9ee7-8b2922ea6df0 [accessed February 8, 2009].

${ }^{4}$ Senator Charles Schumer (D-NY) quoted in Mort Kondrake, "Obama Needs Help in Keeping Promise to Unify Country," Roll Call, November 6, 2008, accessed via RealClearPolitics.com http://www.realclearpolitics.com/articles/2008/11/obama needs help_in keeping pr.html [accessed February 8, 2009].

${ }^{5}$ U.S. Rep. John Lewis (D-GA) quoted in Jennifer Ludden, "Obama Sails To Sweeping, Historic Victory," NPR, November 5, 2008, http://www.npr.org/templates/ story/story.php?storyId=96596393 [accessed February 8, 2009].

${ }^{6} \mathrm{http}: / / \mathrm{www}$.archives.gov/federal-register/electoral-college/2008/electionresults.html (accessed May 26, 2009).

${ }^{7}$ Chris Cillizza, "Friday House Line: House GOP Prospects Grow Dimmer," washingtonpost.com, October 17, 2008, http://voices.washingtonpost.com/thefix/2008/ 10/house line.html [accessed February 28, 2009].

${ }^{8}$ Aaron Blake, "Dems' 19-seat gain not making splash," The Hill, November 5, 2008, http://thehill.com/leading-the-news/dems-19-seat-gain-not-making-splash-200811-05.html [accessed February 8, 2009]. See also, Kondrake, "Obama Needs Help in Keeping Promise to Unify Country." 


\section{Fighting "Change" in Congressional Campaigns | 113}

${ }^{9}$ Cook, Charlie. Cook Political Report, http://www.cookpolitical.com/node/3607 [accessed November 25, 2008]

\section{REFERENCES}

Fenno, Richard F. 1978. Home Style: House Members in Their Districts. Boston: Little, Brown.

Jacobson, Gary C., and Samuel Kernell. 1983. Strategy and Choice in Congressional Elections. New Haven, CT: Yale University Press. 